Article

\title{
Exploring the Dynamics of Responses to Food Production Shocks
}

\author{
Aled Jones * and Bradley Hiller \\ Global Sustainability Institute, Anglia Ruskin University, Cambridge CB1 1PT, UK; bradley.hiller@cantab.net \\ * Correspondence: aled.jones@anglia.ac.uk; Tel.: +44-1223-698931
}

Academic Editors: Riccardo Accorsi and Riccardo Manzini

Received: 2 May 2017; Accepted: 1 June 2017; Published: 6 June 2017

\begin{abstract}
Food production shocks can lead to food crises where access to appropriate quantities and quality of food become inadequate, unaffordable, or unreliable on a major scale. While the physical causes of food production shocks are well researched, the dynamics of responses to them are less well understood. This paper reviews those dynamics and includes evidence gathered via interviews of 44 expert practitioners sourced globally from academia, government, industry, think-tanks, and development/relief organizations. The paper confirms that policy interventions are often prioritised for national interests and poorly coordinated at regional and global scales. The paper acknowledges future compounding trends such as climate change and demographic shifts and suggests that while there are signs of incremental progress in better managing the impacts of shock events, coordinated responses at scale will require a paradigm shift involving major policy, market, and technological advancements, and a wide range of public and private sector stakeholders.
\end{abstract}

Keywords: production shock; food crisis; food price; government responses

\section{Introduction}

The World Economic Forum defines food crises to occur where 'access to appropriate quantities and quality of food and nutrition becomes inadequate, unaffordable or unreliable on a major scale' [1]. Such crises can be regional or global in extent and can result from major shock events. Evidence suggests that a food crisis cannot simply be avoided by having access to sufficient supplies of food as the dynamics of supply and demand are increasingly complex in the modern global agrifood system. For example, Bangladesh experienced severe famine and hunger in the 1970s, not for lack of global food supply but, instead, local food supply, price increases, and speculative behaviour combined and resulted in the deaths of up to 1.5 million people [2-5]. At the global level, the most recent major crisis occurred in 2007/08 — termed the 'world food crisis' [6] — and resulted in a doubling of international wheat and maize prices (over two years) and a tripling of international rice prices (over just a few months) [7]. The World Bank calculated that it forced over 130 million people into poverty [7] and food import bills of developing countries increased by 56\% during 2007/08 [8].

While the adverse effects of the $2007 / 08$ crisis are well known [6,9], there is more speculation around the relative importance of contributing dynamics to such events. Some authors [10] highlight that food commodity prices operate in a complex global system, yet remain broadly consistent with market fundamentals where price is driven by interactions of supply and demand, while others [11] consider that supply-demand interactions cannot fully explain price spikes. Additionally, prices of crops are highly correlated now, given that feedstock grains can be substituted, and so a production shock in one grain can impact the price of another. What emerges from across the literature is that no one dynamic can solely account for past changes in food prices.

Further to identifying the contributing causes to major shock events, market and government responses to food production shocks are complex [10-21] and typically not well quantified. 
Past responses have revealed fundamental market and policy failures in the market-based food architecture [22] and trends suggest that future responses may be complicated by increasingly interconnected inter-country food dependencies [23] and changes in frequency and severity of extreme weather events and climatic changes [24].

Hence, there is a need to better understand the before, during, and after of acute food shock events, which may not only help to manage and avoid such events in the future, but may also reveal some insights into addressing more chronic food insecurity challenges. This paper, therefore, aims to explore this lack of understanding with a specific research objective to better capture expert knowledge that exists in the practitioner community around the likely responses to food production shocks and their societal impacts. The paper uses expert interviews and critical literature reviews to organize and validate existing knowledge on food security challenges associated with food shock events.

The paper confirms that agricultural commodity price spikes are a common market reaction to shock events and that the range of responses from both exporting and importing actors can either assuage or exacerbate impacts. Actors can act largely independently (in self-interest), meaning that at regional and global scale, responses can be poorly coordinated. The paper analyses political, financial, social, and technological factors contributing to actor responses. The paper concludes that greater coordination and action around global agrifood policies; the balancing of sovereign rights and national (food) security interests with reliance on global market efficiencies; and climate change mitigation/adaptation will be required to help ensure that the most vulnerable countries and communities have access to affordable and quality food during shock events.

\section{Materials and Methods}

This paper is derived from research conducted as part of the 'UK-US Taskforce on Extreme Weather and Global Food System Resilience', which examined plausible worst case scenarios of disruption to the global agrifood system caused by extreme weather events. The taskforce developed a conceptual framework for devising and assessing different hypothetical scenarios of disruption to the global food supply chain, fixed around two quantitative reference points: (i) reductions to global crop production; and (ii) resultant consequences for the global food system, such as commodity price. Further, three sets of drivers for those reference points were developed around (i) climate/weather events, (ii) market and policy responses, and (iii) impacts in country, to assess different aspects in disruption pathways. This paper focuses on the 'response' driver; specifically, the most plausible and likely policy and market response pathways, and whether those pathways ameliorate or exacerbate effects of crop production losses and associated market fluctuations.

This paper draws from primary and secondary qualitative data sources, and secondary quantitative data sources. A literature review of both practitioner and academic sources preceded an assessment of typical market impacts based on a structured stakeholder engagement process. A food risk scenario was developed in partnership with the United Kingdom Met Office, based on the 'human dynamics of climate change' food maps [25]. A synthesis of productivity and consumption databases and assessments of impact of availability on traded commodities (from the World Bank, the Food and Agricultural Organisation, the United States Department of Agriculture, and the United Nations ComTrade database) also contributed to construction of the food risk scenario. The food risk scenario, a human dynamics food map, and semi-structured interview questions were provided to 44 expert interviewees drawn globally from academia, government, industry, think-tanks, and development/relief organizations. The questionnaire aimed to understand key stakeholder responses to food production shocks based on a hypothetical scenario of a $20 \%$ shock in one, or all, of the key traded crops (wheat, maize, rice, soy), with particular focus on factors that could exacerbate or ameliorate price increases, and export and import capabilities. Interview durations ranged from 30-60 min and were conducted by telephone.

Snowball sampling (also called chain-referral sampling) was employed as a form of non-probability sampling, which is widely used in qualitative sociological research [26,27]. The method 
requires the identification of an initial set of relevant respondents and then requesting that they suggest other potential subjects who have relevance to the objective of the study [27]. Snowball sampling is recommended by some authors [28], in studies such as this one, where there is a requirement for expert judgement and where access is provided to knowledge or assessments otherwise not available in the public domain. The authors countered the potential limitations of snowball sampling (such as respondents suggesting others with similar characteristics and outlooks [29] and challenges in verifying the eligibility of potential respondents) by actively and deliberately developing and controlling the sample's initiation, progress, and termination [26]. This included sampling from multiple 'entry' points from the outset and targeting respondents from different geographical locations (thirteen countries, including Brazil, Canada, Ethiopia, India, Indonesia, Mexico, New Zealand, Philippines, Singapore, Spain, Switzerland, United Kingdom, and the United States) and sectors (academia, government, industry, think-tanks, and development/relief organizations). Further, to maintain construct validity, rather than aggregating and averaging responses, the authors included the full range of responses from all interviewees, conducting a manual coding analysis to group the responses according to key emergent themes [30]. During interviews, the authors adhered to relevant ethical research standards for United Kingdom universities.

In addition, a final workshop, hosted by the Royal Institute of International Affairs at Chatham House, brought together eight practitioners to review initial findings and highlight any gaps in knowledge. Figure 1 shows the countries from where the expert respondents were based.

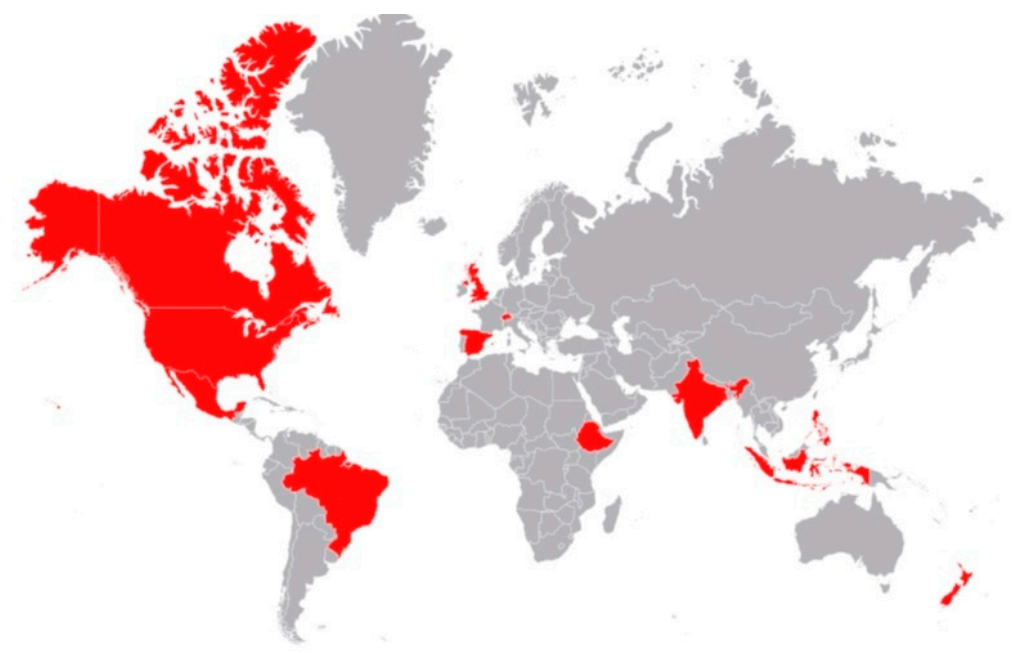

Figure 1. Countries from which the expert respondents were based.

The following section presents the main findings from the combined primary (interviews) and secondary (literature) data sources, while the discussion section then highlights the main factors, identified through these themes, that interact to shape the dynamics of food production shock responses.

\section{Results}

What emerges from the interviews and across the literature is that market and policy responses to food production shocks are complex, typically not well quantified, and that no one cause can be attributed solely to past changes in food prices. Here the two main overarching themes are presented as export or import responses with sub-themes explored within each highlighted the relevant literature or interview excerpts as appropriate. Export responses are those responses, including policy, production capacity, and price, which directly impact the export capacity of a particular country with respect to the supply of food. Import responses are those responses, including policy, price, and distribution, which directly impact the ability of a particular country to import food from global supply chains. 


\subsection{Export Responses}

Some authors $[10,31]$ state that a production shock becomes a global supply shock if trade and export restrictions result. Export responses and agricultural commodity price changes are intrinsically linked-price changes are a signal that something has happened in the supply system. In response to price spikes, counteracting forces often come into play as stakeholders act in self-interest to rebalance supply and demand components. Such forces related to exports may include positive and negative market and policy responses.

Government preparedness and willingness to act during a shock event are important factors in determining the severity and extent of the impact. Some authors [22] point to the escalation of export restrictions by key food exporters in the face of rising food prices in 2007/08 as a reminder of the deeply political nature of food as a commodity. Shocks at the global level can be minimized, delayed, or avoided (or alternatively exacerbated and accelerated) by various government actions. Exporting countries can decide how much of their production will be exported for sale or retained for domestic consumption. Both individually and collectively, such decisions have important influences on agrifood commodity prices and availability and can create many winners and losers.

\section{"The food sovereignty debate is more about politics than food security." Academic Representative, Asia}

Some authors [31] state that trade shocks (related to export restrictions) are one of the great uncertainties in world food markets. If an exporting government perceives food shortages or price rises, they may impose export restrictions (and even complete bans) or enforce technical barriers (such as customs procedures). If there is a concern of increasing price volatility domestically then governments may also intervene to provide stability to domestic markets (although in doing so this may raise prices for others). Government-implemented trade restrictions by several countries in $2007 / 08$ caused a 'run on rice' [32], with prices tripling. Similar actions in the run up to the 2012 crisis were purportedly compounded by adverse weather and drought conditions [33]. Some authors [22] believe that export restrictions undermine trust in the world market as a source of food security.

"Countries need to decide whether they see food as a "globally trade-able commodity" or as a

"strategic national input." Think Tank Representative, Asia

"It may be better not to restrict exports, but evidence shows that countries that do restrict can benefit from it." Academic Representative, Europe

However, only some governments have the capacity and will to impose explicit export restrictions and it is strongly related to the internal political situation. For example, agricultural markets in Russia, India, China, and Vietnam are controlled by the state or state-owned enterprises, whereas private sector actors play a more significant role in countries such as the United States (where an outright export ban has not been issued since the 1970s). In countries not dominated by state-owned enterprises, lobby groups can significantly influence government decision-making. Political pressure to protect domestic interests (e.g., livestock industries, biofuel industries, domestic farmers) may keep domestic food prices low and, therefore, in democracies, voters happy.

"The literature recommends keeping trade moving, but governments need to keep their own people happy." Government Representative, North America

Such reasons for restrictions are witnessed in countries such as Argentina (regularly) and Thailand (in 2008). Notably, while countries, such as the United States, have chosen not to impose explicit export restrictions in recent decades, they can use other means to protect their farmers and domestic markets as necessary. Inflated domestic pricing-the United States domestic wheat price is higher than the global export price-also encourages satisfaction of the domestic market primarily (a food security 
issue) and export markets secondarily. Similarly, China maintains high domestic prices and high domestic production levels. Taxes are also able to be levied at national borders to discourage export (some developing countries regularly do this). However, other countries are sometimes criticized, or praised, for prioritizing international markets over domestic consumers.

"The Brazilian Government sees itself as a provider of grains to international customers, sometimes over domestic needs." NGO Representative, Latin America

"In 2012 in Brazil, in response to production shocks and high commodity prices, in one season farmers planted soybean and some corn and harvested it early and then squeezed in a second crop of corn within the same season. Nowadays, two crop harvests in one season is more common. An exporting country such as Brazil can respond quickly to increases in prices and can self-finance production increases under those conditions." Private Sector Representative, North America

Stakeholders, such as the United States Department of Agriculture (and some authors [8,34]), acknowledge that increases in United States ethanol production, and associated structural changes in the national maize market, have impacted the world's supply and demand balance for total coarse grains [14]. Importantly, some authors attributed increased demand for coarse grains for biofuel production in the EU and United States as a prominent differentiating factor between the 2007/08 world food crisis and earlier events [35].

"Refusal by the United States to waive biofuel policy, particularly after poor harvests of maize, is a response by omission rather than commission." Think Tank Representative, Europe

"To date, biofuel mandates in the United States and Europe have been inflexible and may be unlikely to change until those exporting countries experience extreme conditions." Private Sector Representative, North America

In the literature, there is frequent reference to inter-grain causation between fuel crops and food crops. For example, some authors [31] describe an increased demand for maize (from biofuels) leading to a lower supply of soybean (due to land in the US being allocated to maize production over soybean) and a strong causal link between maize and soybean price shocks. Biofuels accounted for almost half the increase in consumption of major food crops in 2006-07, mostly due to corn-based ethanol produced in the United States [36]. Other authors [22] point to the EU (in 2001) and United States (in 2005) legislation increasing the demand for maize to produce ethanol and vegetable oils to produce biodiesel. Biofuel demand was said to increase prices not only for corn, but for other grains, meat, poultry, and dairy through cost-push and crop and demand substitution effects [8].

Export restrictions were generally not recommended from a market function and efficiency viewpoint, however, there were some suggestions that countries that do restrict exports can benefit, at least initially, particularly in averting the worst effects of a crisis. Furthermore, some supporters argue that current food security and agricultural policies (for example, global trade agreements) do not benefit populations worldwide equally and that, under such conditions, export restrictions are understandable and may be justifiable. However, the dynamic impact of export restrictions and lower domestic prices for commodities can lead to other challenges, such as lower overall global production of important crops.

"There is some lack of faith in international trading systems and some shift to self-sufficiency, which is not open, adaptable or efficient." Research Institution Representative, North America

An important factor influencing the magnitude of any price rise is the state of world food commodity stocks at the time of the shock. In general, if world stocks are high, then the magnitude of increase should be less than if world stocks are low. This also suggests that if multiple shocks occur—where world stocks are lowered and not given time to rebound — then price rises (and associated 
challenges) may continue to increase after each successive event. Exporting countries suffering from shock events may or may not have stockpiles that they can draw down to maintain export output. Where stocks are available, exporting countries may be able to maintain their contractual relationships with importing partners whilst also providing for their own domestic markets throughout the shock event. However, formulating policy based on stock levels is difficult due to a lack of data on current stock levels [37].

"A lack of transparency of food reserves of some major countries means that it is difficult to predict what their reaction will be under shock scenarios and what impact it will have on global agricultural commodity markets." Academic Representative, Europe

Physical and institutional infrastructure can be as important for exporting countries as for importing countries, not only for domestic food security, but in terms of shifting large volumes of export stock quickly. While importing countries can often space out their imports in line with their storage/transport capacities, exporting countries often must shift large volumes quickly once harvested.

"Impacts of extreme weather event may not be on production, but on something else in the agrifood system, for example, physical infrastructure, transport networks, food safety, and follow-on impacts to other industries which contribute to financial markets." Academic Representative, Europe

Exporting countries, such as the United States, Canada, Australia, Brazil, Argentina, and others sometimes have problems exporting agricultural commodities due to infrastructure limitations. For example, the United States transport network from production areas (e.g., the Midwest) to ports (in the Gulf of Mexico) is highly reliant on the Mississippi River. The Mississippi River is limited as a transport route due to increased traffic for movement of other commodities (e.g., shale oil, etc.) and occasional periods of low water levels (such as 2011/12). Countries, such as Canada and Australia, have experienced rail capacity limitations. Russia is dependent on ports for export, many of which are prone to freezing over. Other potential difficulties for such countries include different rail gauge issues, long journeys to sea ports, crowded rail routes, and costly transportation. Export centres can also become impeded and/or disconnected via conflict, e.g., the Black Sea is a key export point for agrifood commodities from Ukraine and Russia via the Bosphorus Strait.

"There are long term capacity issues on critical transport routes, such as the Mississippi River and the Pacific Northwest rail line in the United States. Congestion caused by increasing competition with other commodities, such as shale oil and coal, and impacts of climate change (reduced water levels) are important factors." Think Tank Representative, Europe

In addition to physical infrastructure, institutional and human capacities play significant roles. For example, Brazil and Argentina have been challenged by labour disputes at key export points, which can delay deliveries to importing countries. Such strikes may be more likely during critical times, such as shocks, as unions try to negotiate better conditions for workers.

\subsection{Import Responses}

Demand for food is changing significantly and by 2050 it is expected that there will be an additional 1 to 3 billion more people to feed [38]. Urbanisation trends and changing dietary trends, particularly increased demand for meat-based protein, dairy, and processed foods, called 'nutrition transition' [39], constitute two of the greatest chronic social challenges for the global food security. Increasingly, both developed and emerging countries suffer from lifestyle and diet-related non-communicable diseases (e.g., obesity, diabetes) with associated healthcare challenges [39,40]. Alongside these long-term demographic influences on food import trends there exists a whole host of shorter term factors.

Financial speculation in food commodity and futures markets is of particular interest in academic discussions on the causes of food price spikes [11,13,41], yet its influence remains controversial [42]. 
Increases in the futures markets for grains in 2008 and 2011 reflected market sentiment that prices would continue to rise, which ultimately turned out to be incorrect. Some authors [11] detail how futures traders can base decisions on past trends rather than new information on market fundamentals, making it harder to distinguish fundamental changes to price. Subsequent herd behaviour impedes speculators' abilities of price discovery. Even with the correct information on market fundamentals, traders may not intervene to correct prices where they stand to benefit from the resulting commodity bubble. Speculation can, therefore, amplify price increases. For example, World Bank estimates on the 2008 drought reported that up to $30 \%$ of price increases occurred based on anticipated fallout (from drought impacts and biofuel production on corn crops) rather than the shocks themselves.

"There doesn't have to be a change (blockage) of trade, but just a perception of it can spike prices." Multilateral stakeholder, North America

"Market responses can be inefficient. They can be driven, not by supply shocks, but by incomplete information and panic." Private Sector Representative, North America

Some consumers, particularly in rice-consuming countries (such as India and Bangladesh), purportedly believe that rising food prices are often due to speculative behaviour and/or cartel influence. It was suggested that often governments do not take such consumer perspectives into account when devising or revising policies. Furthermore, elements of corruption and speculation were considered to occur at both national and local scales.

"Some citizens (in some developing countries) believe that when food prices go up, it's due to speculative behaviour (cartels)." Academic Representative, Asia

Panic buying in the market may result when there is speculation of changes in prices and availability, such as when a major exporting country hints at (and/or implements) export restrictions. This can raise prices and lead to irrational behaviours, or rational, but panicked, behaviours. Panic buying responses have led recently to some longer-term stock-building of grains in some Middle East and North Africa (MENA) countries, particularly because of the Arab Spring events.

"Market responses can be inefficient. They can be driven, not by supply shocks, but by incomplete information and panic." Private Sector Representative, North America

Where food security at the national level cannot be achieved through domestic production countries must rely on market purchases. Such purchases require adequate financial capacity to compete with other importing countries and are reliant on well-functioning agrifood commodity trading systems. Both of these factors are tested during periods of inflated prices, export restrictions, and potential panic associated with major production shocks. Under such conditions, countries with the lowest capacities (insufficient foreign reserves/currency) may be unable to meet the grain demands of their populations. For example, while wealthy countries have the capacity to pay inflated prices for agricultural commodities on the open market, some countries-particularly small or medium-sized developing countries reliant on imports-could be squeezed out and come to rely on assistance from relief agencies.

"Those countries that suffer most during a shock event are reliant on imports, and furthermore countries with insufficient foreign reserves are the most vulnerable of those." Academic Representative, Asia

Many importing countries rely on strategic food import arrangements. For example, some countries, such as the UK and Japan, rely on a combination of trade agreements and being able to purchase on the global market for their food security. Other countries, such as Saudi Arabia and China, are entering into long-term contracts and, in some cases, purchasing land in land-abundant 
exporting countries (e.g., Saudi Arabia with Sudan), as part of strategic partnerships for security of supply. In such importing countries, the private sector (and/or state-owned enterprises) is permitted to act in selected roles, but strategic production is controlled by the government. For many importing countries, ensuring a diversity of supply country options helps to manage any region-specific or country-specific production losses. The interconnected nature of inter-country food dependence has increased dramatically over recent decades [23].

"Free Trade Agreements (FTAs) have the capacity to encourage stable and strong agreements between the trading countries, but could sideline poorer countries without FTAs during shocks as there is less 'free' capacity of stock available for them to purchase." Government Representative, Australasia

Transportation of commodities may be exposed and vulnerable to major weather- or conflict-related events via shipping lanes and ports, and some key 'choke' points for global shipping exist. For example, the Suez and Panama canals and the Malacca Strait in the China Sea are considered major importing and exporting bottlenecks. An estimated $80 \%$ of traded rice and most of China's soybean imports are transported via the South China Sea, a route that has a non-trivial risk of naval conflict. In the MENA region, most imports must pass through at least one, and up to three, maritime chokepoints, depending on the origin, route, and destination.

"If conflict-or weather-related shocks make the Suez Canal impassable, this would significantly affect the importing capabilities and food security of Middle East countries." Research Institution Representative, North America

For moving commodities within a country, there is a need for effective public distribution systems to transport imported food products (for example, from coastal port areas) to areas of demand [43]. For large countries with significant intra-national trade, such as Russia, India, and China, these internal transportation routes are critical to transport grain products from areas of food surplus to areas of food deficit and operate at varying levels of efficiency, reliability, and resilience to infrastructure compromise. Beyond infrastructure to move food products, infrastructure to store them also influences responses to shocks. While technologies for bagging grains have improved and silos can be relatively easily constructed, spoilage of products still occurs and storage can be costly.

"If we're worried about food security, then Africa seems to be the most at risk in terms of infrastructure deficiencies." Academic Representative, North America

In response to shock events, periodically countries can alter agricultural trade and tax policies-in particular grain import tariffs-to help stabilise their economies. For example, many countries [22] altered their grain import tariffs during the 2007/08 world food crisis, which purportedly helped to reduce the most adverse consequences. However, the same author describes universal food subsidies as 'costly, regressive, and, once installed, typically hard to remove, jeopardizing future fiscal stability'. International food relief agencies, such as the World Food Programme (WFP), can provide immediate food aid to countries in need, but it does require the cooperation of the recipient country and the necessary infrastructure for distribution. However, food relief can be prone to its own challenges. Issues, such as disorganisation, lack of capacity, bribery, and different food standards/quarantine regulations between countries compromised delivery of the food aid via both ship and overland.

"Harmonised institutional factors would help reduce import impediments during crisis." Academic Representative, Europe

Some countries with self-imposed import restrictions may relax them as a temporary coping strategy during periods of shortage caused by shock events. For example, while GM crops were introduced globally in 1996, very few GM products are available in Europe or Africa, as a result of conscious policies to restrict them. Such policies could be tested during major shock events. 
Similarly, the implementation and/or alteration of import subsidies may help to partially insulate domestic markets from international price increases. Evidence from some countries implementing major import subsidies within a six to twelve-month period of a shock suggests that they can mitigate short-term impacts, but can also lead to unintended consequences, such as cross-border smuggling and major affordability challenges for governments to maintain them, and major political challenges for governments to reverse them.

"Governments, such as some in the Middle East, have altered import subsidies in recent years in response to price spikes." Think Tank Representative, Europe

\section{Discussion}

Here the findings are drawn together against the main factors that may interact to form future trends within food production shocks, namely political, financial, social, and technological issues. Table 1 provides a summary.

Table 1. Summary of main findings from the interviews.

\begin{tabular}{|c|c|}
\hline Factors Identified & Example Issues \\
\hline Political & $\begin{array}{ll}\text { - } & \text { National politics is key } \\
\text { - } & \text { Data is not accurate } \\
\text { - } & \text { International trade and climate policies difficult to agree }\end{array}$ \\
\hline Financial & $\begin{array}{ll}\text { - } & \text { Food and biofuel subsidies } \\
\text { - } & \text { Market speculation } \\
\text { - } & \text { Market integration }\end{array}$ \\
\hline Social & $\begin{array}{l}\text { - Impacts on vulnerable communities } \\
\text { - } \quad \text { Social safety nets }\end{array}$ \\
\hline Technological & $\begin{array}{l}\text { - } \quad \text { Global supply chain management and technology change } \\
\text { (refrigeration and transportation) } \\
\text { - } \quad \text { Tracing and accountability } \\
\text { - }\end{array}$ \\
\hline
\end{tabular}

\subsection{Political Factors}

Strong sentiment emerged from the interviews, and supported by some authors [22], of the largely uncoordinated responses by countries to shock events, each driven by internal political dynamics and national self-interests. This emphasizes the political nature of food as a commodity. In addressing this current lack of coordination, greater political attention—via forums, such as the G20 —needs to be given to global food security and the increasing risk posed by extreme weather events on global stability.

More reliable information about the state of supplies and stocks could help guard against inaccurate perceptions of shortages. For example, initiatives such as the Agriculture Market Information System (AMIS), which has emerged from the G20, provides opportunity for greater political leadership based on information and transparency. However, some interviewed argued for an independent global intelligence unit, similar to the role that the International Energy Agency (IEA) plays for public and private petroleum stocks [44]. Some commentators were pessimistic about achieving political agreement on either a global trading system or effective climate policy.

\subsection{Financial Factors}

Some authors [34] call for major reforms around financial subsidies for crops for energy, specifically ethanol in the United States. Additionally, many commentators call for reductions of 
subsidies for locally-produced crops in regions such as the EU that prevent more efficient crop production from alternative potential exporting nations in regions such as Africa.

There may also be opportunity to better monitor market speculation and commodity trading to provide more predictability, particularly during shock events. Minimising information asymmetry may help prevent unnecessary panic and traders from exploiting price runs. While the EU common regional market has existed in its broad current form for two decades, and has faced significant challenges to its unity recently, other common regional markets, such as in Asia, are considered likely to emerge at some point.

\subsection{Social Factors}

Acute shock events can pose severe challenges for vulnerable communities. For example, malnutrition among pre-schoolers rose during the 2007/08 world food crisis, forcing some children to drop out of school early and rendering the damage long lasting [22]. Additionally, by November 2008, food riots had occurred in some 30 countries as a result of the 2007/08 world food crisis [34].

Increasingly, the urban poor, without the capacity to revert to subsistence farming (and, hence, reliant on purchasing) and barring government controls to shelter them from global market fluctuations, may be the most exposed to shock events and elevated international food prices. Effective and reliable social safety nets will be required to support the neediest.

\subsection{Technological Factors}

There has been a radical shift in power from local growers to international retailers and consumers shaping what and how food products are grown, processed and sold [39]. Global supply chains are complex, include high levels of refrigeration and there is a trend towards processed foods. Advancements in supply chains should focus on increasing resilience and robustness, improving efficiencies, and reducing wastage and having the ability to remote monitor and trace from source to customer.

A combination of technological innovations and management initiatives (e.g., restoration of degraded lands back into production) will need to be driven at scale to shift onto a sustainable agrifood development pathway. Opportunities to increase production whilst minimising emissions from agriculture, as well as focusing on intensification rather than extensification, lie in modern approaches, such as conservation agriculture.

\section{Conclusions}

Evidence from past shock events shows that agricultural commodity price spikes are a common market response. This paper has reviewed the roles and responses of exporting and importing stakeholders and has demonstrated that there are several actions that they can take in response to shock events that can either assuage or exacerbate impacts. Through a set of expert interviews the paper has been able to organize and highlight the key underlying issues relating to global food security, and while it has not led to a new contribution to theory it, nevertheless, provides this important validation.

It is likely that such extreme events will continue to increase in frequency and, hence, the degree of resilience and ability to adapt and respond to those events will determine their impacts on communities. Importantly, action is required to better coordinate political responses, manage financial responses, and invest in social and technological solutions.

Hence, in the interests of reducing the likelihood and adverse impacts of shock events, there is strong impetus for action on climate change mitigation and adaptation, and for improved global agrifood policies on key components of transparency, information sharing, collaboration, and crisis prevention. Reconciling sovereign rights and national (food) security interests with reliance on global market efficiencies will take further negotiation. Ensuring access to affordable and quality food for the most vulnerable countries and the most vulnerable communities, even during shock events, is a benchmark worth aiming for. 
While there are signs of incremental progress, to have an impact at scale will require a paradigm shift involving major policy, market, and technological advancements, with contributions from a wide range of public and private sector stakeholders.

Acknowledgments: The authors extend thanks to the 44 interviewees and workshop participants for their important contribution to the study. The coordination role of the UK Foreign and Commonwealth Office (Bob Phillipson, Jack Westwood, and Simon Sharpe) and Chatham House (Rob Bailey) is also acknowledged. Finally, the authors thank members of the UK-US Taskforce on Extreme Weather and Global Food System Resilience, particularly coordinator Tim Benton, for which this research was undertaken. This work was partly funded by a grant from the UK Science and Innovation Network of the Foreign and Commonwealth Office.

Author Contributions: Aled Jones and Bradley Hiller contributed equally to the writing of this paper. Bradley Hiller conducted the interviews with the forty-four agrifood sector experts. Aled Jones represented the authors on the UK-US Taskforce on Extreme Weather and Global Food System Resilience and coordinated eight practitioners to review the initial findings of the study.

Conflicts of Interest: The authors declare no conflict of interest. The UK Science and Innovation Network of the Foreign and Commonwealth Office had no role in the design of the study; in the collection, analyses, or interpretation of data; in the writing of the manuscript, and in the decision to publish the results.

\section{References}

1. World Economic Forum (WEF). Global Risk Landscape 2015 Report; WEF: Cologny, Geneva, 2015.

2. Ravallion, M. The performance of rice markets in Bangladesh during the 1974 famine. Oxf. Econ. J. 1985, 95, 15-29. [CrossRef]

3. Ravallion, M. Famines and Economics. J. Econ. Lit. 1997, 35, 1205-1242.

4. Sen, A. Poverty and Famines, an Essay on Entitlement and Deprivation; Oxford University Press: Oxford, UK, 1981.

5. Quddus, M.; Becker, C. Food Price Bubbles and the 1974 Bangladesh Famine; Economic Institute: Boulder, CO, USA, 1988.

6. McMichael, P. A food regime genealogy. J. Peasant Stud. 2009, 36, 139-169. [CrossRef]

7. Headey, D.D. The Impact of the Global Food Crisis on Self-Assessed Food Security. World Bank Econ. Rev. 2013, 27, 15-29. [CrossRef]

8. Mittal, A. The 2008 Food Price Crisis: Rethinking Food Security Policies, G-24 Discussion Paper Series. In Proceedings of the United Nations Conference on Trade and Development, Geneva, Switzerland, 10-11 March 2009.

9. Natalini, D.; Jones, A.; Bravo, G. Quantitative Assessment of Political Fragility Indices and Food Prices as Indicators of Food Riots in Countries. Sustainability 2015, 7, 4360-4385. [CrossRef]

10. Headey, D.D.; Fan, S. Reflections on the Global Food Crisis: How Did It Happen? How Has It Hurt? And How Can We Prevent the Next One? Monograph; IFPRI: Washington, DC, USA, 2010.

11. Tadesse, G.; Algieri, B.; Kalkuhl, M.; von Braun, J. Drivers and triggers of international food price spikes and volatility. Food Policy 2014, 47, 117-128. [CrossRef]

12. Evans, A. Feeding the Nine Billion; Chatham House: London, UK, 2009.

13. Timmer, C.P. Reflections on food crises past. Food Policy 2010, 35, 1-11. [CrossRef]

14. Trostle, R. Global Agricultural Supply and Demand: Factors Contributing to the Recent Increase in Food Commodity Prices. Report from the Economic Research Services; US Department of Agriculture: Washington, DC, USA, 2008.

15. Hochman, G.; Rajagopal, D.; Timilsina, G.; Zilberman, D. Quantifying the causes of the global food commodity price crisis. Biomass Bioenergy 2014, 68, 106-114. [CrossRef]

16. Jayasuriya, S.; Mudbhary, P.; Broca, S.S. Food Price Spikes, Increasing Volatility and Global Economic Shocks: Coping with Challenges to Food Security in Asia; RAP (FAO): Bankok, Thailand, 2012.

17. Baffes, J.; Dennis, A. Long-Term Drivers of Food Prices; Policy Research Working Paper 6455; World Bank Development Prospects Group \& Poverty Reduction and Economic Management Network: Washington, DC, USA, 2013.

18. McCalla, A.F. World food prices: Causes and consequences. Can. J. Agric. Econ. 2009, 57, 23-34. [CrossRef]

19. McPhail, L.L.; Du, X.; Muhammad, A. Disentangling corn price volatility: The role of global demand, speculation, and energy. J. Agric. Appl. Econ. 2012, 44, 401-410. [CrossRef] 
20. Götz, L.; Glauben, T.; Brümmer, B. Wheat export restrictions and domestic market effects in Russia and Ukraine during the food crisis. Food Policy 2013, 38, 214-226. [CrossRef]

21. Sarris, A. Weather index insurance for agricultural development: Introduction and overview. Agric. Econ. 2013, 44, 81-384. [CrossRef]

22. Christiaensen, L. Revisiting the Global Food Architecture: Lessons from the 2008 Food Crisis. WIDER Discussion Papers; No. 2009/04; World Institute for Development Economics (UNU-WIDER): Helsinki, Finland, 2009; ISBN 978-92-9230-220-7.

23. D'Odorico, P.; Carr, J.A.; Laio, F.; Ridolfi, L.; Vandoni, S. Feeding humanity through global food trade. Earth's Futures 2014, 2, 458-469. [CrossRef]

24. Intergovernmental Panel on Climate Change (IPCC). Fifth Assessment Report (AR5); IPCC: Geneva, Switzerland, 2014.

25. Met Office (United Kingdom). Human Dynamics of Climate Change. 2014. Available online: http:/ /www. metoffice.gov.uk/media/pdf/j/k/HDCC_map.pdf (accessed on 24 May 2017).

26. Biernacki, P.; Waldorf, D. Snowball Sampling: Problems and Techniques of Chain Referral Sampling. Sociol. Methods Res. 1981, 10, 141-163.

27. Tansey, O. Process Tracing and Elite Interviewing: A Case for Non-Probability Sampling. Polit. Sci. Politics 2007, 40, 765-772. [CrossRef]

28. Christopoulos, D. Peer Esteem Snowballing: A methodology for expert surveys. In Proceedings of the Eurostat Conference for New Techniques and Technologies for Statistics, Brussels, Belgium, 18-20 February 2009; pp. 171-179.

29. Seldon, A.; Pappworth, J. By Word of Mouth: Elite Oral History; Methuen: London, UK, 1983.

30. Kumar, N.; Stern, L.; Anderson, J. Conducting inter-organizational research using key informants. Acad. Manag. J. 1993, 36, 1633-1651. [CrossRef]

31. Headey, D.D. Rethinking the global food crisis: The role of trade shocks. Food Policy 2011, 36, $136-146$. [CrossRef]

32. Brahmbhatt, M.; Christiaensen, L. The run on rice. World Policy J. 2008, 25, 29-37. [CrossRef]

33. Coulibaly, A.L. The Food Price Increase of 2010-2011: Causes and Impacts; Library of Parliament: Ottawa, ON, Canada, 2013.

34. Collier, P. The Politics of Hunger, How Illusion and Greed Fan the Food Crisis. Foreign Aff. 2008, 87, 67.

35. Mitchell, D. A Note on Rising Food Prices; World Bank Policy Research Working Paper 4682; The World Bank Development Prospects Group: Washington, DC, USA, 2008.

36. IMF. Food and Fuel Prices: Recent Developments, Macroeconomic Impact, and Policy Response; IMF (International Monetary Fund): Washington, DC, USA, 2008.

37. Fraser, E.D.G.; Legwegoh, A.; Krishna, K.C. Food stocks and grain reserves: Evaluating whether storing food creates resilient food systems. Environ. Stud. Sci. 2015, 3, 445-458. [CrossRef]

38. World Resources Institute (WRI). Creating a Sustainable Food Future-A Menu of Solutions to Sustainably Feed More Than 9 Billion People by 2050; World Resources Institute: Washington, DC, USA, 2014.

39. Lang, T. Crisis? What Crisis? The Normality of the Current Food Crisis. Agrar. Chang. 2010, 10, 87-97. [CrossRef]

40. Popkin, B. The World Is Fat: The Fads, Trends, Policies and Products that Are Fattening the Human Race; Avery/Penguin: New York, NY, USA, 2009.

41. Lagi, M.; Bar-Yam, Y.; Bertrand, K.Z.; Bar-Yam, Y. The Food Crises: A Quantitative Model of Food Prices Including Speculators and Ethanol Conversion; NECSI: Cambridge, MA, USA, 2011; 56p.

42. Abbott, P.C.; Hurt, C.; Tyner, W.E. What's Driving Food Prices in 2011? Issue Report; Farm Foundation NFP: Oak Brook, IL, USA, 2011.

43. Qureshi, M.E.; Dixon, J.; Wood, M. Public policies for improving food and nutrition security at different scales. Food Secur. 2015, 7, 393-403. [CrossRef]

44. Wright, B. Speculators, Storage, and the Price of Rice; Giannini Foundation of Agricultural Economists: Berkeley, CA, USA, 2008.

(C) 2017 by the authors. Licensee MDPI, Basel, Switzerland. This article is an open access article distributed under the terms and conditions of the Creative Commons Attribution (CC BY) license (http:// creativecommons.org/licenses/by/4.0/). 